\title{
nawis PENGARUH PENYEBARAN FASILITAS SOSIAL TERHADAP SIRKULASI DALAM KOTA DI DESA DAUH PURI KLOD, DENPASAR BARAT
} SPACE

\author{
Oleh: Nyoman Siska Dessy Krisanti ${ }^{1}$
}

\begin{abstract}
Social facilities are central to the welfare of a city.Depending on level of accessibility each infrastructure has, its uses by urban dwellers from all over town, creates a collection of complex movements which very often would generate chaotic urban circulations. An obvious implication one easily observes is a circulation deadlock taking the form as a traffic jam: a condition widely encountered by urban dwellers of DauhPuriKelod of Denpasar.This circumstance provides a ground to conduct a study of impacts of the distribution of social facilities on the urban circulation of the DauhPuriKelod area. The study first investigates the spread of the social facilities. Second, it studies traffics incurred when social facilities are accessed by urban dwellers from certain point of departures, at certain timing; and in a certain manner. And third, it analyses how these traffics contribute to the smooth operation and efficient use of urban road networks available across town. This research applies qualitative research method using naturalistic paradigm. Primary data is obtainedby conducting physical observation and individual interview. The study finds that traffic congestions taking place on circulation paths \& networks across DauhPuriKelod are partially resulted by the widely spread location of numerous social facilities. This mainly due to a lack of city planning that coordinates this issue. To ease this condition, urban dwellers are strongly advised to reduce the use of private vehicles as they rely on heavily on such form of transportations at present.
\end{abstract}

Keywords: Patterns of movement, inner circulation, accessibility, social facilities

\begin{abstract}
Abstrak
Fasilitas sosial berperan penting dalam mendukung operasional sebuah kota dan menjadi hal utama untuk mencapai kesejahteraan sebuah kota. Dilihat dari tingkat aksesibilitas yang dimiliki setiap fasilitas sosial, penggunaan terhadap fasilitas ini akan menciptakan kumpulan gerakan yang kompleks. Tidak jarang jika kondisi ini mengakibatkan sirkulasi perkotaan yang kacau balau. Dampak yang jelas terlihat adalah kekacauan sirkulasi yang mengakibatkan kemacetan lalu lintas. Kondisi inilah yang banyak ditemui oleh penduduk kota di Desa Dauh Puri Kelod, Denpasar Barat, yang menjadi dasar untuk dilakukannya penelitian tentang penyebaran fasilitas sosial dan pengaruhnya terhadap sirkulasi dalam kota. Pertama, penelitian ini menyelidiki mengenai penyebaran fasilitas sosial yang ada di Desa Dauh Puri Klod. Kedua, mengamati lalu lintas yang terjadi ketika fasilitas sosial diakses oleh penduduk kota dari titik keberangkatan tertentu, pada waktu tertentu dan dengan cara tertentu. Dan ketiga, menganalisis bagaimana arus lalu lintas ini berpengaruh terhadap kelancaran operasi dan penggunaan jaringan jalan perkotaan di wilayah tersebut. Penelitian ini menggunakan metode penelitian kualitatif dengan menggunakan paradigma naturalistik. Data primer diperoleh dengan melakukan pengamatan fisik dan wawancara individu. Studi ini menemukan bahwa kemacetan lalu lintas yang terjadi di jalur sirkulasi dan jaringan di seluruh Desa Dauh Puri Kelod sebagian dihasilkan oleh lokasi yang memiliki fasilitas sosial. Hal tersebut terjadi karena kurangnya perencanaan kota yang mengkoordinasikan masalah ini. Untuk memudahkan kondisi ini, penduduk kota sangat disarankan untuk mengurangi penggunaan kendaraan pribadi karena mereka sangat bergantung pada bentuk transportasi seperti saat ini.
\end{abstract}

Kata kunci:Pola Pergerakan, Aksesibilitas, Sirkulasi Dalam Kota, Fasilitas Sosial

1 Program Studi Magister Arsitektur Universitas Udayana Email: siskadessy28@yahoo.com 


\section{Pendahuluan}

Pembangunan fasilitas sosial seperti fasilitas pendidikan, kesehatan, peribadatan, perdagangan dan jasa memiliki peran yang sangat penting dalam mendukung aktivitas ekonomi, sosial dan budaya. Fasilitas sosial merupakan modal dasar dalam memfasilitasi interaksi dan komunikasi antar kelompok serta masyarakat. Fasilitas sosial menjadi sangat penting karena keberadaannya dapat mempengaruhi perkembangan dari suatu kota. Fasilitas sosial yang sangat dibutuhkan oleh masyarakat telah diatur dalam Rencana Tata Ruang Wilayah dan rencana rinciannya, dimana implementasinya dapat dilakukan dengan kerjasama antara Pemerintah Daerah (Pemda) dengan masyarakat maupun kerjasama antara pihak swasta. Dalam hal ini, Pemda perlu melakukan pengawasan untuk melindungi hak masyarakat.

Kawasan Desa Dauh Puri Klod mengalami pertambahan jumlah penduduk yang meningkat. Hal ini berdampak pada perkembangan dan ketersediaan fasilitas sosial yang ada pada kawasannya. Desa Dauh Puri Klod memiliki beberapa fasilitas sosial sebagai wadah yang dapat menunjang kegiatan sosial masyarakatnya, seperti adanya sekolah, rumah sakit, pasar dan tempat ibadah. Seluruh fasilitas sosial tersebut berada pada guna lahan yang tersebar dan berada di pusat kota. Kegiatan penduduk dari dan ke fasilitas sosial akan menimbulkan sebuah pergerakan. Pada beberapa titik jalur aksesibilitas terjadi kepadatan dan menyebabkan perlambatan pergerakan bahkan kemacetan.Kemudian dari sini terlihat bahwa pergerakan yang terjadi telah menimbulkan beban terhadap struktur kota, khususnya pada sirkulasi jaringan jalan.

Fasilitas sosial yang ada di Desa Dauh Puri Klod tidak seluruhnya menyediakan tempat parkir bagi pengunjungnya. Kemudian masyarakat yang mendatangi fasilitas sosial lebih memilih menggunakan kendaraan pribadi, seperti sepeda motor dan mobil. Hal inilah yang kemudian berdampak terhadap sirkulasi pada jaringan jalan di Desa Dauh Puri Klod. Berdasarkan hasil wawancara peneliti dengan pihak terkait, kondisi jaringan jalan tidak mengalami perubahan secara fisik maupun secara kapasitas. Sedangkan jumlah masyarakat yang memanfaatkan fasilitas sosial dengan menggunakan kendaraan pribadi semakin bertambah. Masyarakat jarang memanfaatkan trotoar untuk berjalan kaki menuju fasilitas sosial yang jaraknya dekat dan juga sedikit masyarakat yang memanfaatkan transportasi umum untuk ke tempat tujuan mereka. Keadaan ini disebabkan oleh beberapa faktor, seperti keadaan trotoar yang rusak dan digunakan sebagai tempat parkir, dan tidak nyamannya masyarakat menggunakan transportasi umum. Padahal dengan masyarakat memanfaatkan transportasi umum dan trotoar akan berdampak terhadap sirkulasi lalu lintas, setidaknya dapat mengurangi kemacetan.

Berdasarkan hal tersebut diatas maka dipandang perlu untuk melakukan penelitian mengenai pola penyebaran fasilitas sosial, kemudian bagaimana karakteristik pergerakan dan bagaimana kedua hal ini berdampak terhadap sirkulasi pada jaringan jalan di Desa Dauh Puri Klod. Hasil yang didapat bisa dijadikan solusi untuk memecahkan masalah sirkulasi dalam kota yang sering mengalami kemacetan. 


\section{Metode Penelitian}

Penelitian ini menerapkan metode penelitian kualitatif dengan pendekatan deduktif dan menggunakan paradigma naturalistik. Dalam metode kualitatif, instrumen penelitian adalah peneliti itu sendiri. Peneliti diharapkan sudah memiliki bekal background knowledge tentang topik yang akan diteliti sehingga peneliti akan memiliki gambaran terhadap permasalahan atau fenomena yang terjadi di lapangan.

Data yang diperoleh akan dikumpulkan secara sistematis dari proses observasi dan wawancara serta kuisioner yang telah disebarkan, kemudian dilakukan pengelolaan analisis agar mendapatkan hasil secara terperinci. Jumlah sebaran kuisioner yang dibutuhkan akan dihitung dengan menggunakan rumus Slovin. Kemudian kuisioner disebar dengan teknik proportional cluster random sampling. Setiap klasifikasi terdiri dari desa yang diwakili oleh banjar-banjar yang akan menjadi sampel. Terdapat 11 banjar dan setiap banjar diwakili oleh 30 kepala keluarga. Hal ini dilakukan dengan asumsi bahwa masyarakat yang berada dalam satu banjar mempunyai karakteristik yang sama. Teknik analisis data yang dipergunakan dalam penelitian ini adalah teknik analisis deskriptif kualitatif, yaitu penelitian yang menggambarkan objek penelitian berdasarkan fakta-fakta yang tampak sebagaimana adanya pada saat penelitian dilakukan. Penyajian informasi dilakukan dalam bentuk gambar, tabel, peta dan teks deskriptif. Hasil penelitian berupa kuisioner ditampilkan dalam bentuk tabel, hasil wawancara dijelaskan dengan penjelasan deskriptif kualitatif.

\section{Teori Bangkitan Pergerakan, Teori Lokasi dan Teori Aksesibilitas}

Penelitian ini menggunakan beberapa teori terkait, teori yang akan digunakan adalah teori bangkitan pergerakan, teori lokasi dan teori aksesibilitas. Berikut adalah jabarannya :

\section{a. Teori Bangkitan Pergerakan}

Bangkitan pergerakan atau yang biasa disebut Trip Generation adalah jumlah perjalanan yang terjadi dalan satuan waktu pada suatu zona tata guna lahan. Bangkitan dan tarikan pergerakan digunakan untuk menyatakan bangkitan pergerakan pada masa sekarang yang akan digunakan untuk meramalkan pergerakan pada masa mendatang. Parameter tujuan perjalanan sangat berpengaruh di dalam produksi perjalanan (Levinson; Djafar 2011), yaitu tempat bekerja, kawasan perbelanjaan, kawasan pendidikan, kawasan hiburan. Bangkitan pergerakan adalah suatu proses analisis yang menetapkan atau menghasilkan hubungan antara aktivitas kota dengan pergerakan. Perjalanan ada dua, yaitu home base trip dan no home base trip. Pernyataan tersebut menyatakan bahwa ada dua jenis zona, yaitu zona yang menghasilkan pergerakan dan zona yang menarik pergerakan (Tamin dan Hobbs; Djafar 2011). Bangkitan pergerakan berhubungan dengan penentuan jumlah keseluruhan yang dibangkitkan oleh sebuah kawasan. Parameter tujuan perjalanan sangat berpengaruh di dalam produksi perjalanan, seperti tempat bekerja, kawasan perbelanjaan, kawasan pendidikan, kawasan usaha, kawasan hiburan (Levinson; Djafar 2011).

\section{b. Teori Lokasi}

Teori lokasi merupakan ilmu yang mempelajari mengenai tata ruang sebuah kegiatan ekonomi dan sosial. Dapat juga dikatakan ilmu yang mempelajari mengenai lokasi 
geografis dari sumber-sumber yang potensial dan pengaruhnya terhadap keberadaan berbagai macam kegiatan ekonomi dan sosial (Tarigan 2006; Djafar 2011). Salah satu hal yang dibahas dalam teori lokasi adalah pengaruh jarak terhadap intensitas orang bepergian dari satu lokasi ke lokasi lainnya. Hal ini dapat dikembangkan untuk melihat suatu lokasi memiliki daya tarik tersebut. Terkait dengan lokasi, maka salah satu faktor yang menentukan apakah suatu lokasi menarik untuk dikunjungi atau tidak adalah tingkat kemudahannya untuk dijangkau.

\section{c. Teori Aksesibilitas}

Aksesibilitas adalah suatu ukuran kenyamanan atau kemudahan lokasi tata guna lahan berinteraksi satu sama lain dan mudah atau sulitnya lokasi tersebut dicapai melalui transportasi. Tingkat aksesibilitas pada suatu wilayah dapat diukur berdasarkan pada beberapa variabel, yaitu ketersediaan jaringan jalan, alat transportasi, panjang, lebar jalan dan juga kualitas jalan. Selain itu yang menentukan tinggi rendahnya tingkat akses adalah pola pengaturan tata guna lahan dan keberagaman pola pengaturan fasilitas umum dan fasilitas sosialnya. Seperti keberagaman pola pengaturan fasilitas umum dan fasilitas sosial terjadi akibat berpencarnya lokasi fasilitas umum dan fasilitas sosial secara geografis dan berbeda jenis intensitas kegiatannya. Keadaan yang seperti ini membuat penyebaran lahan dalam suatu wilayah menjadi tidak merata atau heterogen dan faktor jarak bukanlah satusatunya elemen yang menentukan tinggi rendahnya tingkat aksesibilitas (Magribi dan Miro; Parlindungan 2010).

\section{Gambaran Umum Desa Dauh Puri Klod, Denpasar Barat}

Gambaran umum penelitian akan memaparkan secara umum mengenai Desa Dauh Puri Klod. Desa Dauh Puri Klod merupakan salah satu desa baru hasil pemekaran dari Desa Dauh Puri (sekarang Kelurahan Dauh Puri). Desa Dauh Puri Klod merupakan bagian dari Denpasar Barat yang terletak 08036'24"-08041'59'LS dan 115010'23"-115014'14'BT. Luas wilayah Desa Dauh Puri Klod adalah 188 Ha, yaitu 1,47\% dari luas wilayah Kota Denpasar. Batas-batas Desa Dauh Puri Klod, yaitu sebelah Utara adalah Kelurahan Dauh Puri, sebelah Selatan adalah Kelurahan Sesetan/Desa Pedungan, sebelah Barat adalah Desa Dauh Puri Kauh, sebelah Timur adalah Kelurahan Panjer. Desa Dauh Puri Klod terdiri dari 11 banjar, yaitu Banjar Ekasila, Batu Bintang, Bumi Banten,Bumi Kerthi, Bumi Shanti, Bumi Asri, Bumi Sari, Sanglah Barat, Sanglah Utara dan Sanglah Timur. Berdasarkan data rekapitulasi pada tahun 2017, jumlah penduduk Desa Dauh Puri Klod adalah 14.501 dengan 2.004 Kepala Keluarga yang terdiri dari 7.579 laki-laki dan 6.922 perempuan. Kepadatan penduduk di Desa Dauh Puri Klod pada tahun 2017 adalah 7.713 jiwa/km2. Jumlah penduduk tertinggi berada di Banjar Ekasila dengan jumlah penduduk mencapai 2.002 jiwa, hal tersebut dikarenakan wilayah di Banjar Ekasila memiliki lahan terluas dan berada di pusat kota dan merupakan daerah lintas. Lokasi Desa Dauh Puri Klod dapat dilihat pada Gambar 1 dan 2. 


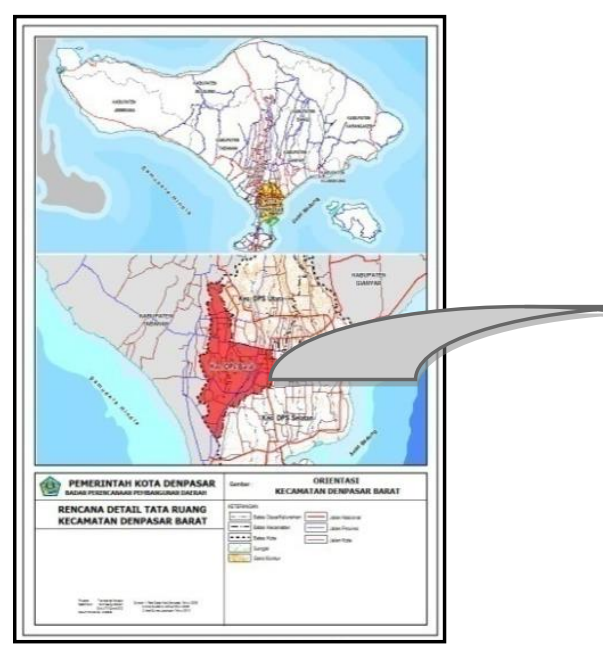

Gambar 1.Peta Kecamatan Denbar Sumber: RDTR Kecamatan Denpasar Barat 2017

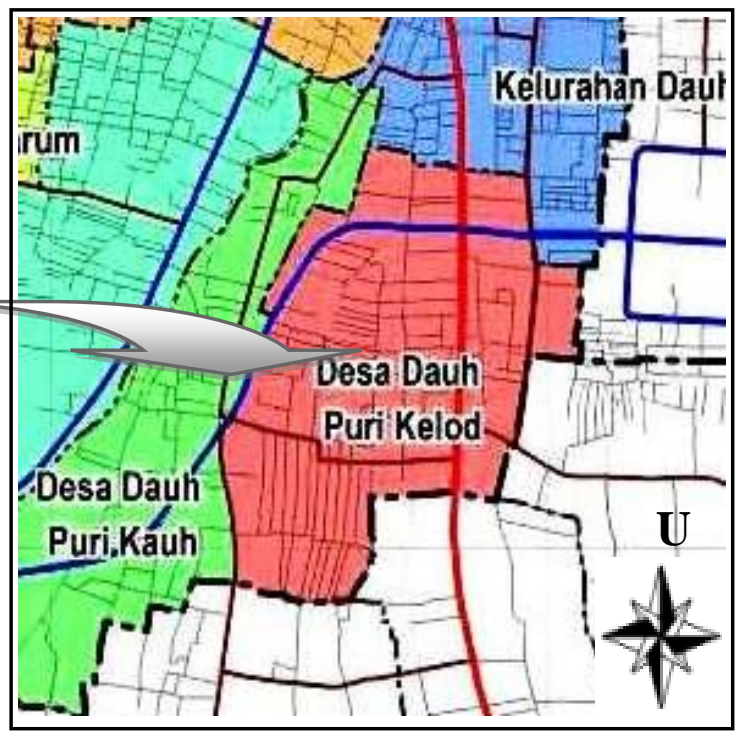

Gambar 2.Peta Desa Dauh Puri Klod

Sumber: RDTR Kecamatan Denpasar Barat 2017

\section{Analisis Penyebaran dan Pemanfaatan Fasilitas Sosial di Desa Dauh Puri Klod}

Desa Dauh Puri Klod memiliki beberapa fasilitas sosial seperti rumah sakit, sekolah, tempat ibadah, dan juga pasar tradisional. Keempat fasilitas sosial yang lokasinya tersebar di wilayah Desa Dauh Puri Klod akan dibahas dalam penelitian ini karena memiliki pengaruh pergerakan yang berdampak terhadap sirkulasi pada jaringan jalan di kawasan yang akan diteliti. Untuk lebih jelas dapat dilihat sebaran fasilitas sosial yang ada di Desa Dauh Puri Klod pada Gambar 3.

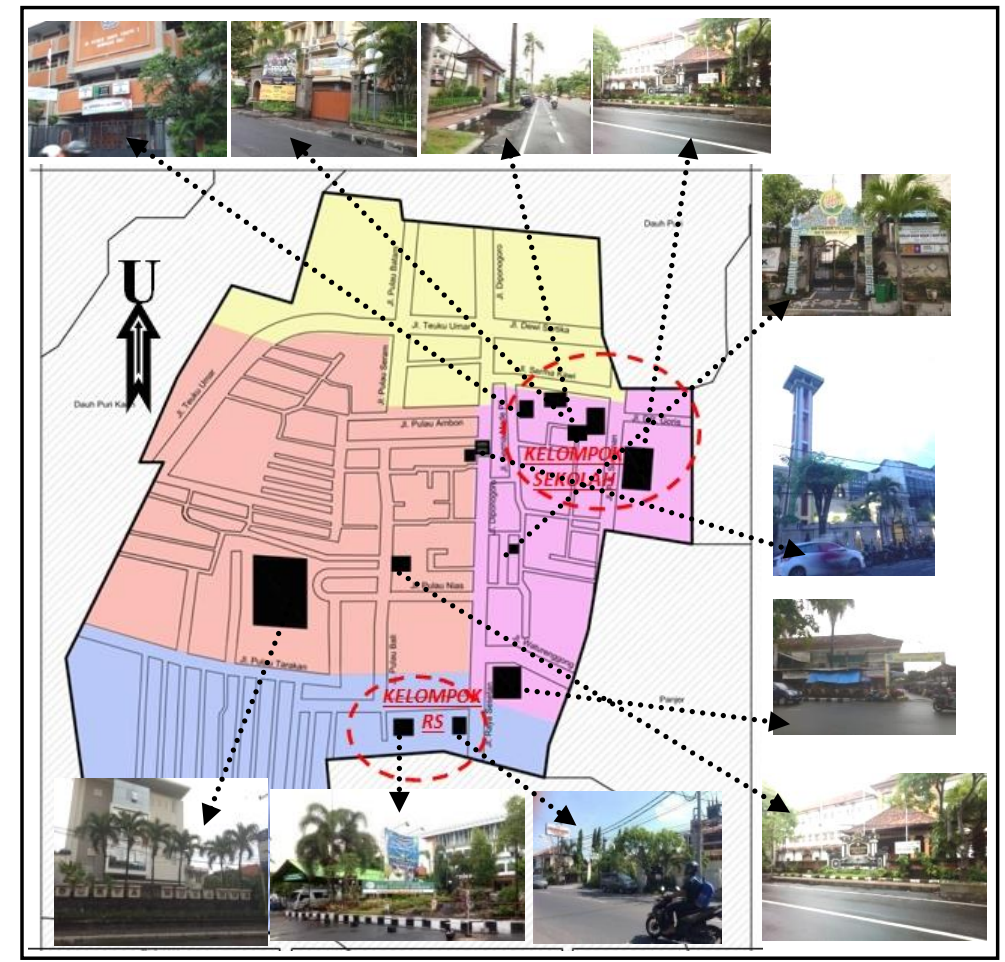

Gambar 3.Sebaran Fasilitas Sosial di Desa Dauh Puri Klod Sumber: Hasil Penelitian Tahun 2018 
Berdasarkan gambar tersebut, sebaran dari keempat jenis fasilitas sosial mengacu kepada pola sebaran acak. Ini dapat dibuktikan dengan lokasi guna lahan yang digunakan oleh keempat jenis fasilitas sosial berada pada satu pusat kota dengan jarak yang tidak teratur. Hal ini menunjukan bahwa kawasan ini tidak terintegrasi antara fungsi yang satu dengan yang lainnya. Selain itu lokasi antara fasilitas sosial satu dengan yang lainnya menyebar tetapi mengelompok didalamnya. Sebagai contoh sekolah dan rumah sakit memilih lokasi yang masih satu area yang cenderung terlihat mengelompok namun terdapat jarak yang tidak teratur antara satu dan yang lainnya. Kemudian diantara rumah sakit dan sekolah ada fasilitas lainnya yang masih satu area, seperti pasar tradisional dan tempat ibadah (masjid). Keberadaan pasar tradisional dan tempat ibadah diantara fasilitas sosial lainnya yang cenderung mengelompok didalam satu area ini menunjukan kawasan ini tidak terintegritas. Hal ini dapat terjadi dikarenakan fasilitas sosial yang tersedia memilih lokasi yang memiliki jalur aksesibilitas yang mudah dijangkau, seperti berada tepat di jalan utama atau jalan arteri, sehingga pola antara fasilitas sosial terlihat tidak teratur atau acak.

Pola sebaran acak pada keempat jenis fasilitas sosial yang ada di Desa Dauh Puri Klod tentu akan berdampak terhadap pola pergerakan masyarakat dalam memanfaatkan fasilitas sosial tersebut. Pola pergerakan masyarakat akan semakin jelas apabila dilihat dari segi karakteristik pergerakannya. Pergerakan masyarakat dari segi jarak, waktu dan moda transportasi yang digunakan menuju fasilitas sosial dapat memberikan dampak terhadap sirkulasi pada jaringan jalan yang ada di Desa Dauh Puri Klod. Berdasarkan observasi lapangan, fasilitas sosial yang ada di Desa Dauh Puri Klod berada dipusat kota dan mudah untuk dijangkau. Beberapa akses menuju ke fasilitas sosial adalah jalur utama yang dapat dilalui oleh berbagai jenis kendaraan dengan berbagai tujuan lain.

\section{Karakteristik Pergerakan Masyarakat Desa Dauh Puri Klod Menuju Fasilitas Sosial}

Beberapa akses menuju ke fasilitas sosial merupakan jalur utama yang dapat dilalui oleh berbagai jenis kendaraan dengan berbagai tujuan dan waktu yang bervariasi. Berikut adalah jabaran dari masing-masing fasilitas sosial yang telah diobservasi berdasarkan karakteristik pergerakannya :

\section{Pasar Tradisional}

Pasar tradisional yang ada di Desa Dauh Puri Klod adalah Pasar Sanglah. Lokasi Pasar Sanglah berada pada tempat yang strategis, yaitu di pusat kota dan dapat diakses dari dua sisi, yaitu dari sisi utara dan barat. Sisi utara dan barat merupakan jalan arteri, sisi barat adalah Jalan Diponegoro dan sisi utara adalah Jalan Waturenggong. Jarak Pasar Sanglah dengan permukiman masyarakat Desa Dauh Puri Klod juga tidak terlalu jauh, berkisar antara 1-5 km. Untuk lebih jelas mengenai karakteristik pergerakan masyarakat menuju Pasar Sanglah dapat dilihat pada Tabel 1. Intensitas kunjungan masyarakat ke Pasar Sanglah dapat dilihat pada Gambar 4. 
Tabel 1. Karakteristik Pergerakan Rumah ke Pasar

\begin{tabular}{ccc}
\hline $\begin{array}{c}\text { Karakteristik } \\
\text { Pergerakan }\end{array}$ & Jumlah & Persentase \\
\hline Jarak : & 306 & $93 \%$ \\
$1-5 \mathrm{~km}$ & 23 & $7 \%$ \\
$>5 \mathrm{~km}$ & & \\
Waktu : & 158 & $48 \%$ \\
$03.00-05.59$ & 132 & $40 \%$ \\
$06.00-08.59$ & 39 & $12 \%$ \\
$>09.00$ & 13 & $4 \%$ \\
Moda Transportasi : & 30 & $9 \%$ \\
Berjalan kaki & 287 & $87 \%$ \\
Sepeda & 20 & $8 \%$ \\
Sepeda Motor & & \\
Mobil & &
\end{tabular}

Sumber: Hasil Penelitian Tahun 2018

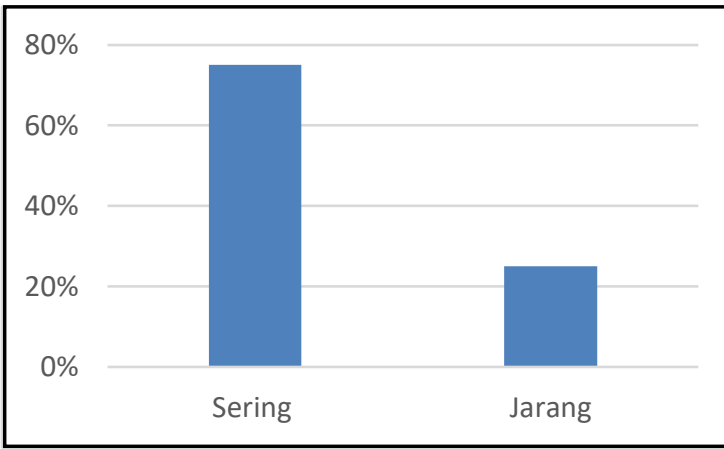

Gambar 4.Intensitas Kunjungan Masyarakat Ke Pasar Sanglah

Sumber: Hasil Penelitian Tahun 2018

Berdasarkan kuisioner dan analisis data yang dilakukan, sebagian besar masyarakat Desa Dauh Puri Klod yang menjadi responden, yaitu sebanyak 93\% atau sekitar 306 masyarakat melakukan pergerakan belanja dengan jarak kurang dari $5 \mathrm{~km}$. Sebanyak $7 \%$ atau sekitar 23 orang melakukan pergerakan untuk belanja sejauh 6-10 km. Intensitas kedatangan masyarakat ke pasar adalah tiga kali dalam seminggu. Waktu kedatangan paling ramai mulai dari pukul 03.00 pagi sampai dengan pukul 09.00 pagi. Jumlah moda transportasi terbesar yang digunakan masyarakat untuk ke pasar adalah sepeda motor, yaitu $87 \%$. Penggunaan sepeda motor dikarenakan efektifitas dari segi waktu dan memudahkan dalam membawa barang belanjaan.

Karakteristik pergerakan masyarakat dari rumah menuju ke Pasar Sanglah ini memberikan dampak terhadap sirkulasi pada jaringan jalan disekitar pasar Sanglah. Apalagi jalan utama menuju pasar Sanglah tidak hanya dilalui oleh orang yang menuju pasar saja, tetapi juga dengan arah tujuan lainnya. Menumpuknya jumlah kendaraan pada jalan sekitar pasar dikarenakan waktu kedatangan yang hampir bersamaan. Selain itu pengguna jalan lain juga melewati jalan utama menuju pasar ini, mengingat jalan utama menuju pasar adalah jalan arteri. Perlambatan pergerakan pun terjadi, ditambah lagi dengan kegiatan disekitar pasar 
yang juga mempengaruhi perlambatan pergerakan. Kegiatan tersebut seperti, kendaraan pengunjung pasar yang diparkir dibahu jalan, adanya masyarakat yang berjalan dibahu jalan dikarenakan sebagian trotoar digunakan untuk berjualan.

\section{Rumah Sakit}

Desa Dauh Puri Klod memiliki tiga rumah sakit yang terdiri dari satu rumah sakit pemerintah dan dua rumah sakit swasta. Rumah sakit pemerintah tersebut adalah Rumah Sakit Umum Pusat Sanglah (RSUP Sanglah) dan dua rumah sakit swasta, yaitu Rumah Sakit Prima Medika dan Rumah Sakit Surya Husada. RSUP Sanglah berlokasi di Jalan Pulau Nias, kemudian RS Prima Medika yang berlokasi di Jalan Raya Sesetan dan RS Surya Husada yang berlokasi di Jalan Pulau Serangan. Ketiga rumah sakit jaraknya saling berdekatan dan tidak lebih dari $5 \mathrm{~km}$, kemudian jarak ketiga rumah sakit dengan permukiman penduduk di Desa Dauh Puri Klod juga tidak lebih dari $7 \mathrm{~km}$. Pada tabel 2 dapat dilihat karakteristik pergerakan masyarakat menuju rumah sakit. Intensitas kunjungan masyarakat dapat dilihat pada Gambar 5.

Tabel 2. Karakteristik Pergerakan Rumah ke RS

\begin{tabular}{ccc}
\hline $\begin{array}{c}\text { Karakteristik } \\
\text { Pergerakan }\end{array}$ & Jumlah & Persentase \\
\hline Jarak: & 214 & $93 \%$ \\
$>7 \mathrm{~km}$ & 115 & $7 \%$ \\
$<7 \mathrm{~km}$ & & \\
Waktu : & 198 & $48 \%$ \\
$07.00-08.59$ & 132 & $40 \%$ \\
$09.00-11.59$ & & $70 \%$ \\
Moda Transportasi : & 230 & $30 \%$ \\
Sepeda Motor \\
Mobil
\end{tabular}

Sumber: Hasil Penelitian Tahun 2018

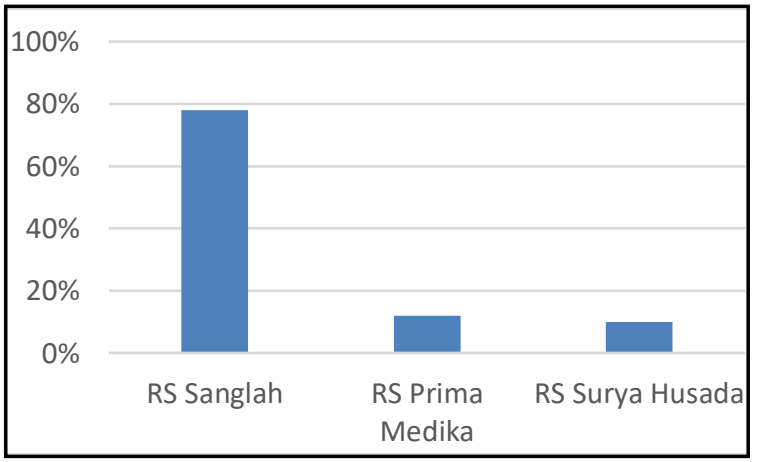

Gambar 5.Intensitas Kunjungan Masyarakat ke rumah sakit

Sumber: Hasil Penelitian Tahun 2018

Berdasarkan kuisioner yang disebar oleh peneliti kepada responden, ruman sakit yang paling banyak didatangi oleh masyarakat Desa Dauh Puri Klod adalah Rumah Sakit Sanglah. Hal ini menunjukan bahwa pergerakan dengan tujuan rumah sakit yang paling 
besar adalah ke Rumah Sakit Sanglah. Jarak ketiga rumah sakit dengan rumah penduduk Desa Dauh Puri Klod yang berjarak diatas $7 \mathrm{~km}$ adalah sebanyak 65\% atau sekitar 214 orang dan sisanya $35 \%$ atau sekitar 115 orang berjarak kurang dari $7 \mathrm{~km}$. Moda transportasi terbanyak yang digunakan adalah sepeda motor, yaitu sekitar $70 \%$ atau 230 orang. Sisanya sebanyak $30 \%$ atau sekitar 100 orang memilih menggunakan mobil. Waktu yang dipilih oleh masyarakat untuk pergi-pulang menuju rumah sakit, baik dalam rangka menjenguk kerabat atau berobat adalah pada jam 09.00-11.59 dan 18.00-20.59 setelah pulang kerja. Sebanyak $60 \%$ datang pada waktu pagi hari dan $40 \%$ datang pada waktu sore hari. Sementara waktu tempuh yang diperlukan adalah 63\% atau sekitar 207 orang mengatakan kurang dari 15 menit dan sisanya 37\% atau sekitar 123 orang mengatakan perlu waktu lebih dari 15 menit menuju rumah sakit.

Lokasi yang menjadi tempat berdirinya ketiga rumah sakit mudah diakses karena berada pada kawasan yang strategis. Dilihat dari karakteristik pergerakan masyarakat menuju rumah sakit ini menimbulkan pergerakan dan membentuk sebuah pola pergerakan karena akses yang dilalui oleh masyarakat tidak selalu sama, tergantung di area mana mereka tinggal. Akses sekitar rumah sakit juga tidak hanya dilalui oleh pengunjung rumah sakit saja, tetapi semua masyarakat dengan segala arah tujuan. Hal ini akan memberikan dampak terhadap sirkulasi pada jaringan jalan di sekitar area rumah sakit.

\section{Sekolah}

Jumlah sekolah yang ada di Desa Dauh Puri Klod lebih dari 20 sekolah dan tersebar di seluruh kawasan Desa Dauh Puri Klod Sekolah dan berada di lahan yang jenisnya beragam, ada sekolah yang memanfaatkan bangunan publik seperti balebanjar, ada juga yang berdiri pada lahan yang terletak di tempat yang strategis. Beberapa sekolah yang merupakan yayasan berada pada satu lahan mulai dari tingkat Taman Kanak-Kanak (TK) sampai dengan Sekolah Menengah Atas (SMA). Pada penelitian ini, tidak semua sekolah akan dipaparkan dalam penelitian, namun peneliti hanya mengamati beberapa sekolah yang memberikan dampak signifikan terhadap sirkulasi jalan dan sebaliknya. Hal ini dilakukan karena beberapa sekolah memiliki karakteristik yang sama. Sekolah yang memberikan dampak yang cukup signifikan pada sirkulasi jalan di Desa Dauh Puri Klod adalah Sekolah Yayasan Santo Yoseph. Jumlah anak yang bersekolah di Desa Dauh Puri Klod dapat dilihat pada Gambar 6.

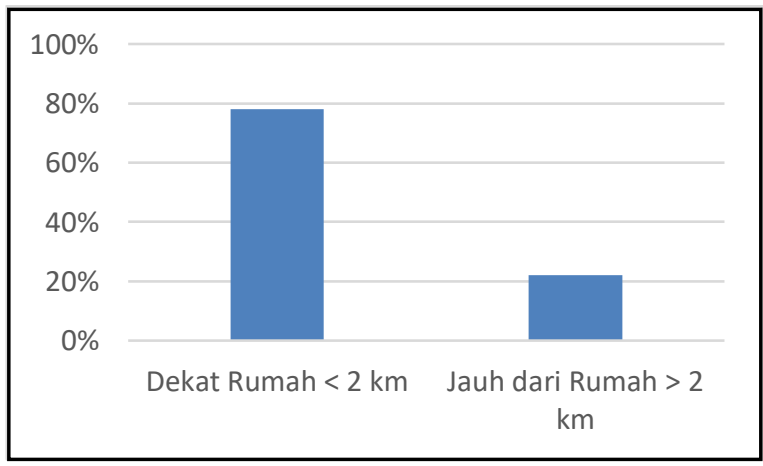

Gambar 6.Jumlah Anak yang Bersekolah di Desa Dauh Puri Klod

Sumber: Hasil Penelitian Tahun 2018 
Berdasarkan kuisioner, 78\% masyarakat Desa Dauh Puri Klod menyekolahkan anak mereka di dekat rumah. Seperti Taman Kanak-Kanak dekat rumah dan Sekolah Dasar Negeri yang masih dalam satu wilayah desa. Alasannya karena lokasi yang dekat dari tempat tinggal sehingga memudahkan untuk mengantar jemput. Selain itu dari segi biaya juga terjangkau karena dapat memanfaatkan Bantuan Operasional Sekolah (BOS) bagi yang bersekolah di sekolah negeri. Karakteristik pergerakan masyarakat dari rumah ke sekolah dapat dilihat pada Tabel 3.

Tabel 3. Karakteristik Pergerakan Masyarakat dari Rumah ke Sekolah

\begin{tabular}{|c|c|c|c|c|c|c|c|c|c|c|}
\hline \multirow{2}{*}{$\begin{array}{c}\text { Karakteristik } \\
\text { Pergerakan }\end{array}$} & \multicolumn{2}{|c|}{ TK } & \multicolumn{2}{|c|}{ SD } & \multicolumn{2}{|c|}{ SMP } & \multicolumn{2}{|c|}{ SMA } & \multicolumn{2}{|c|}{ PT } \\
\hline & $\sum$ & $\%$ & $\sum$ & $\%$ & $\sum$ & $\%$ & $\sum$ & $\%$ & $\sum$ & $\%$ \\
\hline Jarak: & & & & & & & & & & \\
\hline $1-5 \mathrm{~km}$ & 142 & $95 \%$ & 210 & $84 \%$ & 58 & $48 \%$ & 35 & $44 \%$ & 19 & $30 \%$ \\
\hline $6-10 \mathrm{~km}$ & 8 & $5 \%$ & 40 & $16 \%$ & 62 & $52 \%$ & 45 & $56 \%$ & 18 & $28 \%$ \\
\hline$>10 \mathrm{~km}$ & - & - & - & - & - & - & - & - & 28 & $42 \%$ \\
\hline Moda & & & & & & & & & & \\
\hline Transportasi : & 142 & $95 \%$ & 210 & $84 \%$ & 58 & $48 \%$ & 35 & $44 \%$ & 19 & $30 \%$ \\
\hline Berjalan Kaki & 8 & $5 \%$ & 40 & $16 \%$ & 62 & $52 \%$ & 45 & $56 \%$ & 18 & $28 \%$ \\
\hline Mobil & - & - & - & - & - & - & - & - & 28 & $42 \%$ \\
\hline
\end{tabular}

Sumber: Hasil Penelitian Tahun 2018

Pada waktu pergi tujuan ke sekolah terjadi persamaan di semua jenjang pendidikan. Sebagian besar jam pergi tujuan sekolah TK, SD, SMP, SMA dan PT, dilakukan pada jam 06.00-08.00 sebanyak 80\% dan pergi ke sekolah pada jam 11.00-12.00 sebanyak $20 \%$. Untuk waktu pulang dari sekolah adanya keberagaman waktu diantara setiap jenjang pendidikan. Berikut adalah jumlah persentase terbanyak dan waktu yang digunakan untuk melakukan perjalanan pulang: 1) TK (100\%) pada jam 09.00-11.59, 2) SD (75\%) pada jam 12.00-14.59, 3) SMP (35\%) pada jam 15.00-17.59, d) SMA (28\%) pada jam 15.00-17.59, e) PT (78\%) pada jam 15.00-17.59. Dalam melakukan perjalanan ke sekolah, sebagian besar responden TK dan SD membutuhkan waktu tempuh yang sama, yaitu kurang dari 15 menit untuk sampai disekolah masing-masing. Sedangkan untuk SMP, SMA dan PT membutuhkan waktu tempuh selama 16-30 menit untuk sampai di sekolah/kampus masingmasing.

\section{Tempat Ibadah}

Berdasarkan data dari Desa Dauh Puri Klod pada tahun 2016, masyarakat di Desa Dauh Puri Klod memeluk atau memiliki kepercayaan yang beragam. Ada yang memeluk agama Islam dengan jumlah 1.759 orang laki-laki dan 1.736 orang perempuan. Agama Kristen Protestan dengan jumlah pemeluk 738 orang laki-laki dan 691 orang perempuan. Agama Kristen Katolik dengan jumlah pemeluk 509 orang laki-laki dan 475 orang perempuan. Agama Hindu dengan jumlah pemeluk 4.295 orang laki-laki dan 3.816 orang perempuan. Agama Budha dengan jumlah pemeluk 387 orang laki-laki dan 359 orang prempuan. Dilihat dari angkanya, jumlah pemeluk terbanyak adalah pemeluk agama Hindu, hal ini dikarenakan Desa Dauh Puri Klod merupakan bagian dari Pulau Bali yang memang 
masyarakat aslinya memeluk agama Hindu. Untuk lebih jelas, grafik jumlah penganut agama yang ada di Desa Dauh Puri Klod dapat dilihat pada Gambar 7.

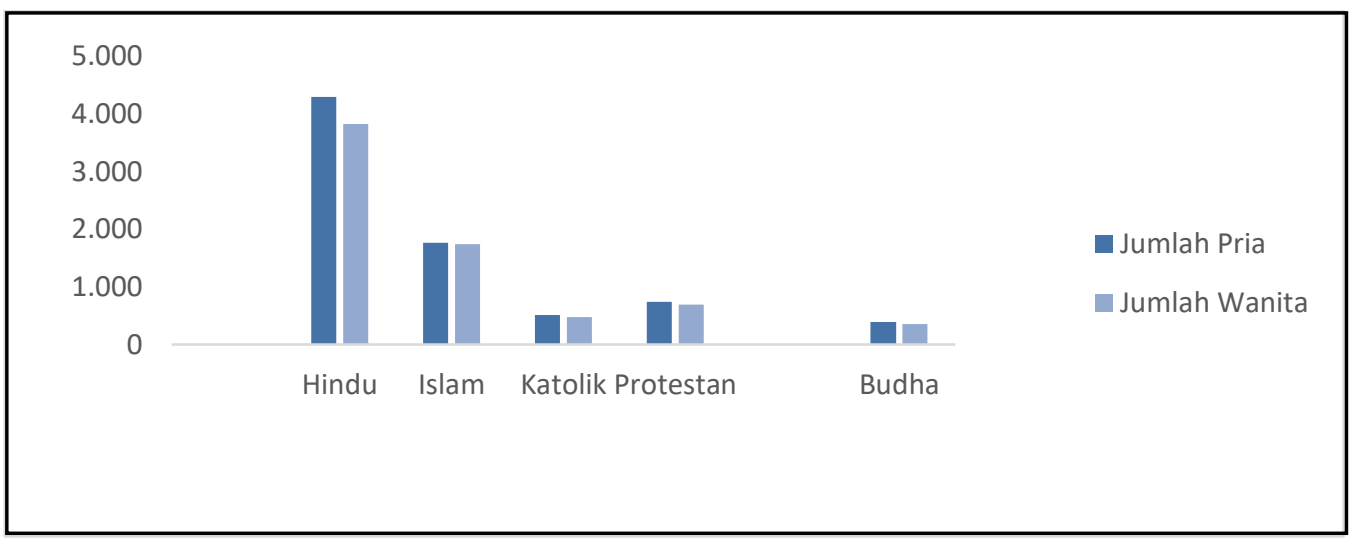

Gambar 7.Jumlah Penganut Agama di Desa Dauh Puri Klod Tahun 2016 Sumber: Hasil Penelitian Tahun 2018

Desa Dauh Puri Klod memiliki beberapa tempat ibadah, selain pura juga terdapat masjid yang terletak di Jalan Diponegoro. Masjid ini bernama Masjid An-Nur dan berada tepat dipinggir jalan arteri sehingga memudahkan masyarakat muslim untuk mencapainya. Jarak dari rumah masyarakat Desa Dauh Puri Klod yang memanfaatkan adanya Masjid An-Nur adalah rata-rata $5 \mathrm{~km}$. Moda transportasi yang digunakan adalah sepeda motor. Pada harihari tertentu, seperti pada saat Jumat'an mulai dari pukul 12.00-14.00 siang, area disekitar masjid akan sangat penuh dan krodit. Tidak adanya lahan parkir yang cukup membuat masyarakat yang berkunjung ke masjid memarkir kendaraan mereka dibadan jalan. Tentunya hal tersebut menyebabkan kemacetan dan perlambatan pergerakan, sehingga menghambat arus lalu lintas

\section{Pengaruh Pergerakan Masyarakat dalam Mengakses Fasilitas Sosial terhadap Sirkulasi pada Jaringan Jalan di Desa Dauh Puri Klod}

Keadaan sirkulasi pada jaringan jalan dipengaruhi oleh beberapa faktor, seperti adanya fasilitas sosial. Beberapa fasilitas sosial yang dapat memberikan dampak terhadap sirkulasi pada jaringan jalan adalah sekolah, pasar, rumah sakit dan lain sebagainya. Dalam mencapai tujuan menuju fasilitas sosial tersebut, masyarakat menggunakan moda transportasi. Dan moda transportasi yang paling banyak digunakan adalah kendaraan pribadi (roda dua). Saat ini banyak masyarakat yang melakukan perjalanan dengan menggunakan kendaraan pribadi dengan alasan efisiensi waktu. Akibatnya adalah jumlah kendaraan di jalan menjadi semakin banyak dan penuh. Ditambah lagi dengan adanya kendaraan yang parkir dibahu jalan, karena fasilitas sosial yang menjadi tujuan masyarakat tidak menyediakan tempat parkir yang cukup. Hal itu berdampak terhadap sirkulasi pada jaringan jalan dan nantinya akan menimbulkan kemacetan.

Dalam melakukan perjalanan setiap harinya, sebagian besar masyarakat di Desa Dauh Puri Klod melakukan perjalanan sendiri dengan kendaraan masing-masing. Hanya sedikit yang melakukannya dengan diantar jemput maupun bersama keluarga. Untuk perjalanan antarjemput lebih banyak dilakukan oleh perjalanan menuju kesekolah. Hal ini dikarenakan 
anak sekolah pada tingkat TK sampai SMP belum bisa dan tidak mendapatkan ijin untuk membawa kendaraan sendiri. Berdasarkan hasil wawancara dengan masyarakat yang bersangkutan, tidak memungkinkan untuk menaiki transportasi umum karena arah tujuan yang tidak sesuai.

Keberadaan transportasi umum sebenarnya dapat membantu mengurangi kepadatan pada jaringan jalan. Namun sayangnya, masyarakat di Desa Dauh Puri Klod sebagian besar tidak tertarik dan enggan menggunakan angkutan umum sebagai moda transportasi seharihari. Alasanya pun beragam, ada yang dikarenakan faktor keamanan dan kenyamanan serta ada juga yang beralasan bahwa arah tujuan tidak sesuai dengan arah transportasi umum. Sesungguhnya, apabila pelayanan transportasi umum dilakukan dengan baik dan dapat menjangkau wilayah yang luas serta memuaskan penumpang, maka jumlah kendaraan pribadi di jalan raya dapat menjadi lebih sedikit. Masyarakat yang memiliki tujuan singkat atau pendek juga seharusnya lebih memanfaatkan pedestrian atau trotoar dibandingkan dengan menggunakan kendaraan bermotor. Sayangnya tidak semua keadaan trotoar di Desa Dauh Puri Klod dalam keadaan yang nyaman untuk digunakan, seperti berlubang, rusak sampai digunakan sebagai tempat berjualan sehingga masyarakat enggan memanfaatkan trotoar untuk mencapai tujuan mereka.

Selain itu, tempat parkir pada setiap fasilitas sosial juga perlu diperhatikan. Tidak semua fasilitas sosial memiliki tempat parkir yang sesuai dan cukup untuk jumlah pengunjung yang datang. Di Desa Dauh Puri Klod, fasilitas sosial yang memiliki tempat parkir yang cukup hanya pada Rumah Sakit. Untuk pasar, sekolah dan tempat ibadah, tempat parkir tidak cukup dan bahkan ada yang tidak memiliki tempat parkir, sehingga kendaraan terpaksa parkir di bahu jalan dan bahkan ada yang menggunakan trotoar sebagai tempat untuk memarkirkan kendaraan. Untuk lebih jelas mengenai ruas jalan yang sering mengalami kemacetan, dapat dilihat pada Gambar 8.

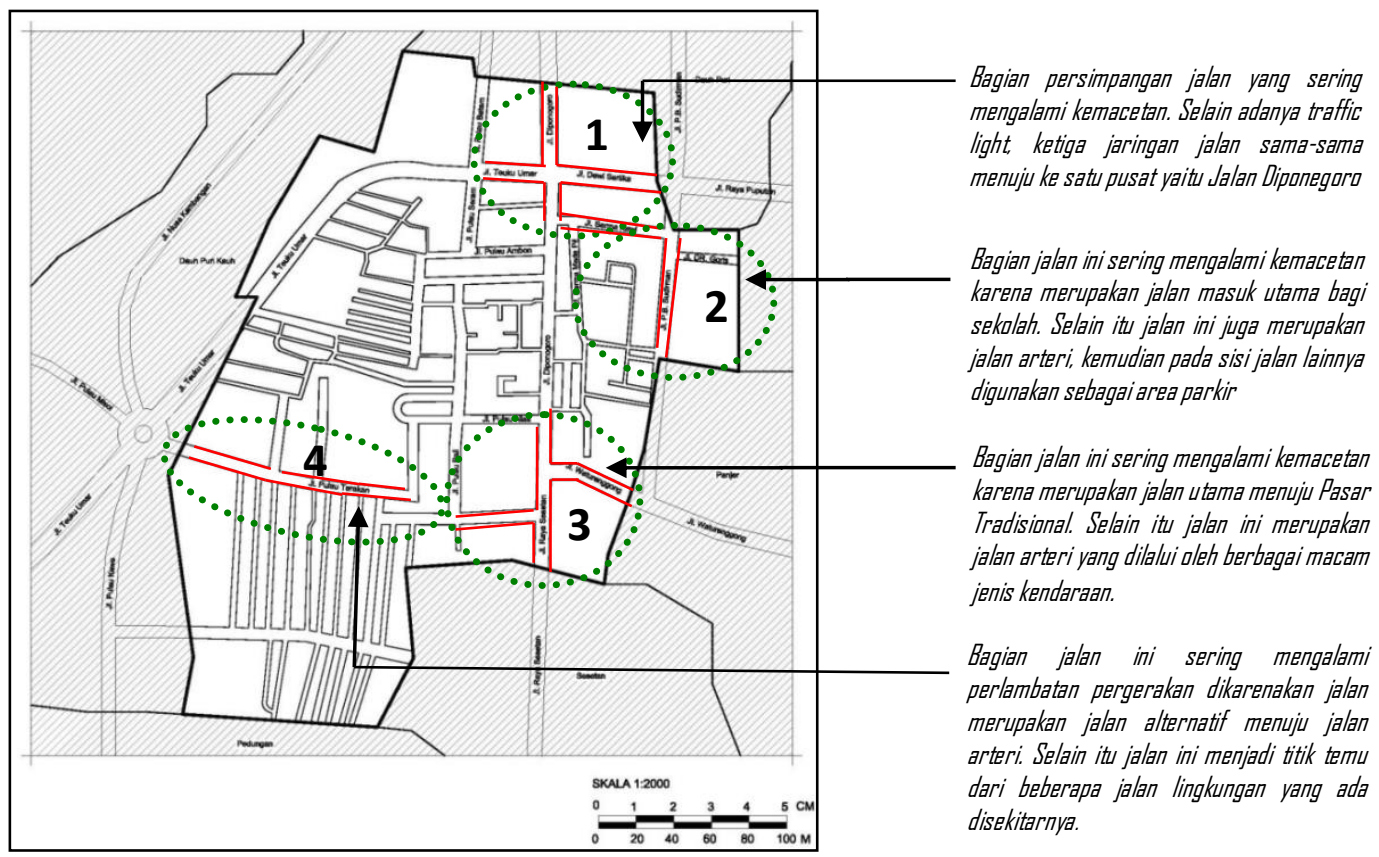

Gambar 8.Jaringan Jalan di Desa Dauh Puri Klod Sumber: Hasil Penelitian Tahun 2018 
Berdasarkan gambar 8, menunjukan bahwa bagian dari beberapa ruas jalan yang sering mengalami perlambatan pergerakan dan bahkan tidak jarang sampai menimbulkan kemacetan di kawasa Desa Dauh Puri Klod. Terjadinya perlambatan pergerakan dan kemacetan dapat disebabkan oleh beberapa faktor, salah satunya adalah adanya fasilitas sosial. Pada titik 1, 2, 3 dan 4 kemacetan sering terjadi pada pagi, siang dan sore hari.

Pada titik satu merupakan persimpangan yang menghubungkan beberapa jalan menuju ke satu titik, sehingga pada pertemuan ini banyak kendaraan dari tiga arah menuju ke satu titik yang mengakibatkan perlambatan pergerakan dan bahkan sering terjadi kemacetan. Adanya traffic light membantu sirkulasi lalu lintas pada area ini, walaupun pada jam-jam sibuk seperti pagi hari (07.00-09.00), siang hari (12.00-14.00) dan sore hari (16.00-18.00) tetap sering terjadi kemacetan.

Titik kedua merupakan kawasan pendidikan, yaitu Yayasan Santo Yoseph, jenjang pendidikan dimulai dari TK sampai dengan SMA dan juga Universitas Udayana dengan jam sekolah mulai dari pagi sampai sore. Jalanan sekitar area ini akan dipadati oleh kendaraan yang parkir di bahu jalan untuk mengantar atau menjemput siswa. Bahkan kendaraan siswa SMA diparkir di bahu jalan sehingga menyebabkan kemacetan.

Pada titik ketiga merupakan kawasan pasar tradisional yang tentu menjadi penyebab kemacetan dan perlambatan pergerakan. Selain itu pada jalan utama menuju pasar merupakan jalan arteri yang dilalui oleh berbagai macam kendaraan dengan berbagai macam arah tujuan. Pada titik empat merupakan area persimpangan, jalan-jalan lingkungan akan menuju jalan arteri untuk mencapai tujuan mereka. Perlambatan pergerakan pun sering terjadi karena banyaknya kendaraan yang melintas dari jalan lingkungan menuju jalan arteri.

Pada titik keempat merupakan kawasan pemukiman penduduk. Jalan lingkungan akan langsung menuju jalan utama, yaitu Jalan Tarakan untuk ke tempat tujuan selanjutnya. Pada jam-jam sibuk, seperti pagi hari (07.00-09.00), siang hari (12.00-14.00) dan sore hari (16.00-18.00) Jalan Tarakan mengalami perlambatan pergerakan dan sampai menimbulkan kemacetan.

\section{Kesimpulan}

Desa Dauh Puri Klod merupakan salah satu wilayah yang terletak di pusat Kota Denpasar. Wilayah ini memiliki fasilitas sosial yang cukup lengkap untuk menunjang kegiatan sosial dan interaksi sosial dimasyarakat. Adanya beragam fasilitas sosial yang disediakan oleh pemerintah atau pihak swasta tentu menimbulkan pergerakan karena fasilitas sosial yang tersedia berada pada guna lahan yang berbeda dan menyebar. Pergerakan masyarakat dari dan ke fasilitas sosial yang terjadi berhubungan dengan aksesibilitas dan sirkulasi dalam kota.

Berdasarkan hasil penelitian serta tanggapan masyarakat Desa Dauh Puri Klod yang telah bersedia menjadi responden, maka dapat disimpulkan sebagai berikut :

1. Fasilitas sosial yang ada di Desa Dauh Puri Klod dapat dimanfaatkan dengan baik oleh seluruh masyarakat, khususnya oleh masyarakat Desa Dauh Puri Klod. Seluruh fasilitas 
sosial ini, seperti rumah sakit, sekolah, tempat ibadah dan pasar tradisional berada pada lokasi atau guna lahan yang berbeda. Lokasi yang berbeda ini tersebar di wilayah Desa Dauh Puri Klod. Sebaran fasilitas sosial ini akan membentuk pola sebaran, dan pola sebaran fasilitas sosial yang ada di Desa Dauh Puri Klod adalah pola sebaran acak. Termasuk dalam pola sebaran acak karena jarak antara fasilitas sosial tidak teratur. Selain itu fasilitas sosial juga menyebar dalam beberapa area kemudian mengelompok didalamnya. Pola sebaran acak ini terjadi karena setiap fasilitas sosial memilih area yang memiliki jalur aksesibilitas yang baik untuk memudahkan masyarakat dalam memanfaatkan fasilitas sosial yang telah disediakan, baik oleh pemerintah atau dari pihak swasta.

2. Karakteristik pergerakan yang terjadi di kawasan Desa Dauh Puri Klod dari segi jarak, apabila ditempuh dari permukiman penduduk menuju fasilitas sosial yang tersedia di desa mereka rata-rata adalah $5 \mathrm{~km}$ dengan waktu tempuh 15-20 menit. Moda transportasi yang digunakan oleh masyarakat adalah $85 \%$ kendaraan pribadi berupa sepeda motor. Penggunaan sepeda motor dapat menguntungkan masyarakat dari segi waktu dan penggunaannya lebih efektif dibandingkan dengan kendaraan roda empat/mobil. Pergerakan menuju fasilitas sosial yang paling banyak terjadi adalah pergerakan menuju pasar tradisional dan pergerakan menuju sekolah. Waktu pergerakan mengalami perlambatan pada jam-jam sibuk, seperti pagi hari saat segala aktifitas diluar rumah dimulai (pukul 07.00-09.00). Kemudian siang hari pada saat jam istirahat/makan siang (12.00-14.00), serta jam pulang sekolah. Dilanjutkan sore hari saat jam pulang kerja (16.00-18.00).

3. Pola sebaran fasilitas sosial di Desa Dauh Puri Klod dan karakteristik pergerakan masyarakat dalam memanfaatkan fasilitas sosial mempengaruhi pola pergerakan yang berdampak terhadap sirkulasi pada jaringan jalan di Desa Dauh Puri Klod. Berdasarkan hal tersebut, sirkulasi di Desa Dauh Puri Klod cenderung mengalami perlambatan pergerakan dan bahkan kemacetan pada area fasilitas sosial karena jumlah kendaraan yang lewat melebihi kapasitas jalan. Hal ini dikarenakan semua masyarakat menggunakan kendaraan pribadi dalam menunjang kegiatan sehari-hari.

\section{Rekomendasi}

Berdasarkan hasil pengamatan yang telah dilakukan oleh peneliti di Desa Dauh Puri Klod mengenai sebaran fasilitas sosial, karakteristik pergerakan dan dampaknya terhadap sirkulasi pada jaringan jalan, ada beberapa upaya yang perlu dilakukan agar tidak terjadi kemacetan arus lalu lintas yang lebih parah, sehingga dapat mengurangi beban pada jaringan jalan, yaitu:

1. Pemerintah mengoptimalkan keberadaan dan fungsi trotoar sebagai penunjang masyarakat untuk berjalan kaki. Berjalan kaki dapat menjadi pilihan masyarakat menuju fasilitas sosial yang jaraknya cukup dekat dari rumah.

2. Adanya lahan parkir yang cukup bagi fasilitas sosial. Kendaraan yang parkir di bahu jalan sangat mengganggu dan membahayakan pengguna jalan lainnya, untuk itu diharapkan semua fasilitas sosial dapat menyediakan tempat parkir bagi pengunjungnya. 
3. Masyarakat ikut bekerja sama untuk kelancaran sirkulasi pada jaringan jalan di Desa Dauh Puri Klod, dengan menggunakan transportasi umum. Pemerintah juga diharapkan kerjasamanya untuk hal ini. Pemerintah diharapkan dapat menyediakan transportasi umum yang memiliki banyak arah tujuan, aman dan nyaman, sehingga masyarakat tidak ragu lagi untuk menggunakan transportasi umum.

Penelitian ini diharapkan dapat memperkaya refrensi pustaka dalam bidang perancangan desa/kota, khususnya dalam tata guna lahan dan pengembangan sistem sirkulasi pada jaringan jalan. Hasil penelitian ini diharapkan dapat menjadi refrensi yang berguna untuk memahami dan mengembangkan lebih lanjut penelitian semacam ini atau kajian yang lebih mendalam.

\section{Daftar Pustaka}

Atmodiwirio, S. (2000). Managemen Pendidikan Indonesia. Jakarta: Ardadizya Jaya.

Badaron, S.F. (2014). Pergerakan Lalu Lintas Akibat Tata Guna Lahan. Fakultas Teknik Sipil. Universitas Brawijaya Malang.

Badan Pusat Statistik Kota Denpasar Tahun 2015.

Baja, S. (2009). Perencanaan Tata Guna Lahan Dalam Pengembangan Wilayah. Sulawesi:Andi.

Banghart, F.W. (1973). Educational Planning. New York:Macmillan.

Cahyani, A.K. (2004). Kondisi Pelayanan Fasilitas Sosial di Kecamatan BanyumanikSemarang Berdasarkan Persepsi Penduduk. Fakultas Teknik. Universitas Udayana.

Djafar, F. (2011). Karakteristik Pola Pergerakan Penduduk Kawasan Peri Urban Kota Medan. Fakultas Teknik. Universitas Sumatera Utara.

Effendi, R. (2014). Jaminan Kenyamanan Pejalan Kaki Dalam Tata Kelola Transportasi di Kota Yogyakarta. Fakultas Ilmu Sosial. Universitas Negeri Yogyakarta.

Herlina, A. (2006). Alih Fungsi Trotoar. Peminat Politik Seni dan Budaya. Jakarta.

Hotrin, R. (2011). Analisis Prioritas Penanganan Jaringan Jalan Strategis Terhadap Pengembangan Wilayah Di Kabupaten Humbang Hasundutan. Perencanaan Pengembangan Wilayah dan Pedesaan. Univeritas Sumatera Utara.

Indrawan, I. (2010). Pengantar Managemen Sarana Dan Prasarana Sekolah. Yogyakarta:CV. Budi Utama.

Kristiana, D. (2010). Kajian Pola Pergerakan Penduduk Ulang Alik dan Pelayanan Transportasi Umum di Zona Kota Pusat dan Kota Pinggiran Kota Surakarta. Fakultas Geografi. Universitas Muhammadiyah Surakarta.

Kusnandar, E. (2013). Dimensi Kendaraan Yang Operasional. Jurnal Ilmiah.

Luhur, A. B. (2010). Pengaruh Infrastruktur Ekonomi dan Sosial Terhadap Pertumbuhan Ekonomi di Indonesia Tahun 2006-2013. Universitas Negeri Yogyakarta.

Masruri, A. (2004). Pengaruh Pola Penggunaan Lahan Terhadap Sistem Pergerakan Pada Kawasan Pusat Kota Brebes.Fakultas Teknik, Universitas Diponegoro.

Parlindungan, B. (2010). Analisis Pengaruh Tingkat Aksesibilitas Wilayah Terhadap Perkembangan Kecamatan di Kota Medan. Universitas Sumatera Utara.

Patton, M. (1990). Qualitative Evaluation and Research Methods. Beverly Hills : SAGE Publication.

Permana, M. A. (2016). Pola Persebaran Industri Bulu Mata Palsu di Kabupaten Purbalingga. Fakultas Keguruandan Ilmu Pengetahuan. Universitas Muhammadiyah Purwokerto.

Raditya, D. (2003). Kajian Struktur Ruang Kota Berdasarkan Pola Pergerakan. Fakultas Teknik Sipi. Institut Teknologi Bandung. 
Ramdha, M. (2007). Keberadaan Fasilitas Sosial dan Fasilitas Umum. Fakultas Teknik. ITB.

Ruspanto, J. (2002). Pengaruh Pendapatan Terhadap Mobilitas dan Pola Pergerakan Penduduk Captive. Universitas Diponegoro.

Sabari, Y.H.(2006). Struktur Tata Ruang Kota. Yogyakarta : Pustaka Belajar.

Salim, H. T. (2001).Pergerakan Lalu Lintas Di Perkotaan Akibat Tata Guna Lahan. Udayana Bali.

Setiohadi, I. (2008). Karakteristik dan Pola Pergerakan Penduduk Kota Batam dan Hubungannya Dengan Perkembangan Wilayah Hinterland.Teknik Sipil. Universitas Diponegoro Semarang.

Suminar, R. E. (2010). Karakteristik dan Pola Pergerakan Penduduk di Kawasan Pinggiran Kota Yogyakarta. Fakultas Teknik. Universitas Gajah Mada.

Suryani, Y. (2011). Teori Lokasi Dalam Penentuan Pembangunan Lokasi Pasar Tradisional. Seminar Nasional Ekonomi Manajemen Dan Akuntansi (SNEMA). Universitas Negeri Padang.

Tangke, M.P. (2010). Pendirian Rumah Ibadah. Teologi Hukum Dan Politik. Jakarta.

Tugino. (2014). Mari Membangun Desa. Jakarta.

\section{Ucapan Terima Kasih}

Penulis mengucapkan terimakasih kepada dosen pembimbing yang telah memberikan banyak masukan untuk penelitian ini. Terimakasih juga untuk seluruh keluarga yang selalu mendukung dan mendoakan kelancaran penelitian. Penulis juga mengucapkan terimakasih kepada seluruh masyarakat Desa Dauh Puri Klod dan instansi terkait yang telah mendukung dan memberikan informasi mengenai penelitian ini. 